\title{
SISTEM PENDUKUNG KEPUTUSAN PENERIMAAN PEGAWAI DI LPF SURABAYA MENGGUNAKAN METODE SIMPLE ADDITIVE WEIGHTING BERBASIS ANDROID
}

\section{MAULANA ALFIANSYAH}

Teknik Informatika, Fakultas Teknik

Universitas Maarif Hasyim Latif, Sidoarjo, Indonesia

e-mail :maulana-alfiansyah@student.umaha.ac.id

\begin{abstract}
ABSTRAK
Kualitas pegawai sangat penting bagi berlangsungnya sebuah lembaga pendidikan. Oleh karena itu dibutuhkan sebuah sistem yang membantu bagian kepegawaian dalam rangka mencari pegawai baru pada pelaksanaan tes calon pegawai baru. Pelaksanaan tes pagawai di Lembaga Pendidikan Al Falah Surabaya masih menggunakan kertas dalam memasukkan nilai tes yang telah dilakukan. Kemudian merekap nilainilai tersebut dan membandingkannya untuk mendapatkan hasil pelamar nilai tertinggi. Sistem Pendukung Keputusan merupakan system yang tepat untuk membantu pelaksanaan pencarian pegawai baru dengan menentukan hasil akhir secara cepat dan tepat dari nilai tes yang telah dimasukkan oleh bagian kepegawaian atau sumber daya manusia di Lembaga Pendidikan Al Falah Surabaya. Metode perhitungan yang dipakai untuk sistem ini ialah Simple Additive Weighting dengan menggunakan bobot pada tiap-tiap kriteria tes. Sistem bisa digunakan di perangkat mobile dan menggunakan database MySQLi dibantu dengan PHP. Dengan adanya sistem pendukung keputusan ini diharapkan akan mempermudah proses seleksi calon pegawai baru di Lembaga Pendidikan Al Falah Surabaya jika sistem ini diterapkan. Sistem pendukung keputusan ini sangat bermanfaat untuk menentukan hasil output peserta tes yang terbaik dari tes-tes yang sudah dilakukan. Perhitungan yang digunakan juga sesuai dengan studi kasus karena kriteria yang digunakan menggunakan bobot dalam perhitungannya. Implementasinya juga sangat mudah dengan memasang aplikasi pada smartphone penguji tes masing-masing.
\end{abstract}

Kata kunci : penerimaan pegawai, android, simple additive weighting, decision support systems, sistem pendukung keputusan

\section{PENDAHULUAN}

Di dalam sebuah lembaga pendidikan kualitas pegawai sangatlah penting untuk berlangsungnya kegiatan. Karena di dalam lembaga pendidikan semua pegawai memungkinkan menjadi contoh bagi anak-anak yang bersekolah di lembaga pendidikan itu. Oleh karena itu dibutuhkan suatu cara untuk memperoleh calon pegawai yang diinginkan lembaga pendidikan. Adapun dalam hal ini suatu lembaga pendidikan seperti Lembaga Pendidikan Al Falah Surabaya mempunyai cara untuk mencari calon pegawai berdasarkan kriteria yang diinginkan. Akan tetapi proses seleksi masih menggunakan kertas untuk menilai dan menghitung dan membandingkan lagi hasilnya. Proses ini mungkin memakan waktu dan memungkinkan terjadinya kesalahan dalam perhitungan hasilnya. Maka dari itu dibutuhkan solusi untuk merancang sistem penerimaan pegawai baru. Sistem pendukung keputusan ini sangat berguna pada bagian sumber daya manusia ketika melaksanakan tes calon pegawai baru dengan cara yang mudah dan menggunakan waktu yang sangat singkat untuk mengetahui hasil siapakah orang yang akan lolos tes dari kriteriakriteria yang sudah ditentukan.

\section{METODE PENELITIAN}

Metode yang dipakai untuk penelitian ini adalah Simple Additive Weighting. Metode penjumlahan terbobot adalah isitilah yang sering dikenal untuk metode SAW. Metode ini dapat membantu untuk pengambilan keputusan pada suatu kasus. Metode ini lebih efisien dikarenakan waktu yang dibutuhkan dan diperlukan untuk perhitungan lebih cepat. Perhitungan dalam metode ini adalah yakni yang menghasilkan nilai paling besar adalah yang akan dipilih sebagai pilihan atau alternatif yang terbaik. Konsep dari metode SAW adalah menemukan penjumlahan terbobot pada rating kinerja untuk tiap-tiap alternatif untuk semua atribut. Perhitungan dapat sesuai yang diinginkan jika alternatif yang terpilih telah memenuhi kriteria yang ditetapkan. Metode ini memerlukan proses normalisasi matriks keputusan ke dalam suatu skala yang nantinya 
akan bisa dibandingkan dengan semua rating alternatifnya.

Didalam metode saw ada proses perhitungan normalisasi pada nilai. Terdapat dua cara jika $j$ ialah atribut keuntungan (benefit) dan jika $j$ ialah atribut biaya (cost).

$$
r_{i j}= \begin{cases}\frac{x_{i j}}{\max _{i} x_{i j}} & \text { Jika } \mathrm{j} \text { adalah atribut keuntungan } \\ \frac{\min _{i} x_{i j}}{x_{i j}} & \text { Jika } \mathrm{j} \text { adalah atribut biaya }\end{cases}
$$

$$
\text { Keterangan: }
$$

$r_{i j} \quad$ : nilai rating kinerja ternormalisasi

$x_{i j} \quad$ : nilai atributyang dimiliki dari setiap kriteria

$\max _{i} x_{i j}$ : nilai paling besar dari setiap kriteria

$\min _{i} X_{i j}$ : nilai paling kecil dari setiap kriteria

benefit : jika nilai paling besar adalah terbaik

cost : jika nilai paling kecil adalah terbaik

dimana $r_{i j}$ adalah rating kinerja ternormalisasi dari alternatif $A_{i}$ pada atribut $C_{j}$ Dengan $i$ adalah alternatif dan $j$ adalah kriteria.

Pada studi kasus ini semua kriteria yang bernilai terbesar adalah terbaik. Jadi digunakan rumus normalisasi nilai atribut keuntungan (benefit). Setelah mendapatkan nilai normalisasi selanjutnya adalah menghitung hasil akhir/nilai prefrensi $V_{i}$ dengan rumus (2).

$$
V_{i}=\sum_{j=1}^{n} w_{j} r_{i j}
$$

Keterangan:

$V_{i}$ : rangking untuk setiap alternatif

$w_{j}$ : nilai bobot dari setiap kriteria

$r_{i j}$ : nilai rating kinerja ternormalisasi

Nilai $V_{i}$ yang paling besar menunjukkan bahwa alternatif atau peserta tersebut terpilih.

\section{Prosedur Penerimaan Pegawai}

Prosedur penerimaan pegawai di Lembaga Pendidikan Al Falah Surabaya adalah dengan mengikuti sejumlah tes calon pegawai atau kriteria penilaian calon pegawai yakni sebagai berikut :

a. Tes Al-Qur'an

Tes ini menguji kemampuan baca Al-Qur'an calon pegawai di Lembaga Pendidikan Al Falah.

b. Tes Praktek

Tes praktek adalah tes praktek yang berkaitan dengan posisi apa yang dilamar oleh calon pegawai.

c. Tes Wawasan Keislaman

Tes ini mengukur seberapa paham calon pegawai dengan pengetahuan seputar wawasan keislaman

d. Tes Wawancara

Tes ini seperti pada tes wawancara umumnya yakni tentang seputar dunia kerja.

Untuk mengurangi kesamaan nilai di antara calon pegawai atau pelamar. Penulis sudah meminta izin untuk menambahkan dua kriteria untuk bahan perhitungan yakni nilai IPK/nilai sekolah dan lama pengalaman kerja sesuai posisi yang dilamar.

\begin{tabular}{l|l}
\multicolumn{2}{c}{ Tabel 1. Bobot kriteria tes } \\
\hline \multicolumn{1}{c}{ Nama Tes } & Bobot \\
\hline a. Tes Al-Qur'an/Mengaji & $: 35 \%$ \\
\hline b. Tes Praktek & $: 35 \%$ \\
\hline c. Tes Wawasan Keislaman & $: 10 \%$ \\
\hline d. Tes Wawancara & $: 10 \%$ \\
\hline e. IPK/Nilai Sekolah & $: 5 \%$ \\
\hline f. Pengalaman Kerja & $: 5 \%$ \\
\hline
\end{tabular}

Bobot pada tabel 1 telah didiskusikan penulis bersama bagian SDM dan sedikit dikembangkan untuk kepentingan penulisan penelitian. Jika dari perhitungan nilai ditemukan hasil akhir nilai yang sama persis antara pelamar maka selanjutnya sistem akan menentukan pelamar yang akan dimunculkan pada output ialah secara default.

Dalam pelaksanaannya di lapangan nilai mengaji dan nilai wawasan Islam digabung menjadi satu. Akan tetapi pada penelitian ini penulis sudah meminta izin untuk dikembangkan. Jadi pada penelitian ini nilai tes mengaji dan wawasan Islam dibedakan menjadi dua bagian. Maka nilainya dibuat sama.

\section{HASIL DAN PEMBAHASAN}

Uji coba program dilakukan berdasarkan sampel data selesksi tes pelamar bagian administrasi keuangan yang dilakukan oleh

\begin{tabular}{|c|c|c|c|c|c|c|}
\hline Nama & $\begin{array}{l}:= \\
\sqrt[\pi]{0} \\
\overline{0} \\
\sum\end{array}$ & 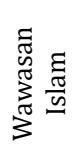 & 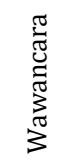 & $\frac{\frac{y}{d}}{\frac{\pi}{\pi}}$ & 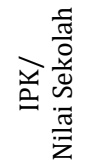 & 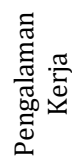 \\
\hline Abdul Q. & 80 & 80 & 79 & 45 & 83.4 & 0 \\
\hline Alfan D. & 60 & 60 & 74 & 30 & 80.5 & 0 \\
\hline Catur A. & 85 & 85 & 73 & 50 & 74 & 0 \\
\hline Imam $\mathrm{T}$. & 60 & 60 & 73 & 15 & 81.5 & 0 \\
\hline Ismiyati & 80 & 80 & 76 & 35 & 88.5 & 1 \\
\hline Nur R. & 80 & 80 & 72 & 65 & 81 & 9 \\
\hline Rizky K. & 70 & 70 & 75 & 10 & 84 & 1 \\
\hline Wildan H. & 80 & 80 & 77 & 50 & 78 & 2 \\
\hline
\end{tabular}
Lembaga Pendidikan Al Falah Surabaya pada tanggal 4 Juli 2019. Diikuti oleh delapan orang.

Proses uji coba aplikasi dilakukan langsung lewat smartphone dengan mengkoneksikan dengan localhost pada laptop. 


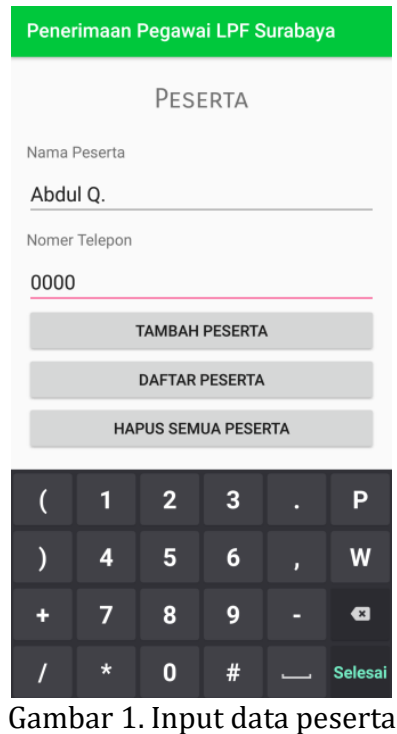

Pada Gambar 1. pertama-tama untuk uji coba masukkan data diri peserta yakni nama dan nomer telepon pada bagian Daftar Peserta pada aplikasi.

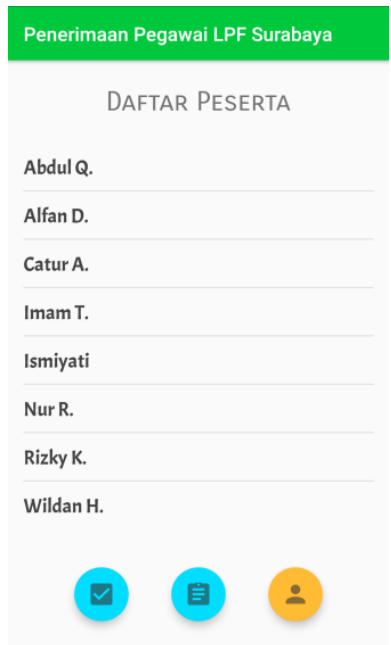

Gambar 2. Daftar peserta

TES MEngaJI (35\%)

ID Peserta

7

Nama Peserta

Abdul Q.

Masukkan Nilai Tes Mengaji

80

MASUKKAN NILAI

Gambar 3. Input nilai tes

Selanjutnya pada gambar 2. dilakukan proses pendaftaran pada semua peserta seperti contoh di atas. Di contoh tersebut nomer telepon diisi 0000 karena privasi. Setelah semua peserta diinputkan maka akan tampil di bagian Daftar Peserta.

Selanjutnya pada gambar 3. dimasukkan nilai-nilai tes pada menu nilai untuk setiap peserta yang tersedia di program. Lalu dimasukkan nilai pada nilai tes yang lainnya dengan cara yang sama.

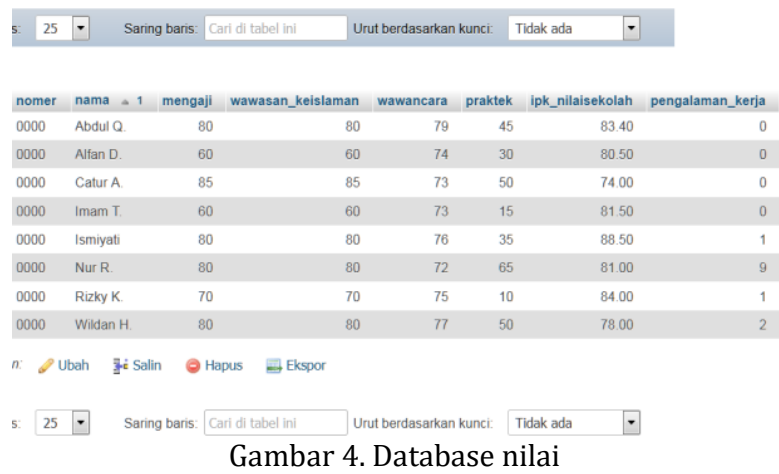

Pada gambar 4. Setelah nilai tes dimasukkan semua, maka nilai tes akan tersimpan dalam database dan siap untuk diolah menjadi nilai normalisasi dan diurutkan berdasarkan perhitungan metode Simple Additive Weighting.

\section{Proses Perhitungan Metode $S A W$}

Selanjutnya dilakukan perhitungan nilai normalisasi pada setiap kriteria tes untuk setiap peserta. Caranya sesuai dengan rumus metode SAW pertama-tama cari nilai maksimal pada kasus ini. Contoh nilai maksimal pada nilai mengaji diperoleh oleh Catur A. dengan nilai 85 . Maka nilai normalisasi pada kolom mengaji adalah seperti berikut :

=> Peserta Abdul Q. pada kolom mengaji $r_{1.1}=80 / 85=0,941176470588240$

=> Peserta Alfan D. pada kolom mengaji $r_{2.1}=60 / 85=0,705882352941180$

=> Peserta Catur A. pada kolom mengaji $r_{3.1}=85 / 85=1$

=> Peserta Imam T. Pada kolom mengaji $r_{4.1}=60 / 85=0,705882352941180$

=> Peserta Ismiyati pada kolom mengaji $\mathrm{r}_{5.1}=80 / 85=0,941176470588240$

=> Peserta Nur R. pada kolom mengaji $r_{6.1}=80 / 85=0,941176470588240$

=> Peserta Rizky K. Pada kolom mengaji $r_{7.1}=70 / 85=0,823529411764710$

$=>$ Peserta Wildan H. Pada kolom mengaji $r_{8.1}=80 / 85=0,941176470588240$

Nilai maksimal pada wawasan keislaman adalah : 85

=> Peserta Abdul Q. pada kolom wawasan islam $r_{1.2}=80 / 85=0,941176470588240$

=> Peserta Alfan D. pada kolom wawasan islam $r_{2.2}=60 / 85=0,705882352941180$

=> Peserta Catur A. pada kolom wawasan islam $\mathrm{r}_{3.2}=85 / 85=1$ 
=> Peserta Imam T. Pada kolom wawasan islam $r_{4.2}=60 / 85=0,705882352941180$

=> Peserta Ismiyati pada kolom wawasan islam $r_{5.2}=80 / 85=0,941176470588240$

=> Peserta Nur R. pada kolom wawasan islam $\mathrm{r}_{6.2}=80 / 85=0,941176470588240$

=> Peserta Rizky K. Pada kolom wawasan islam $r_{7.2}=70 / 85=0,823529411764710$

=> Peserta Wildan H. Pada kolom wawasan islam $\mathrm{r}_{8.2}=80 / 85=0,941176470588240$

Nilai maksimal pada wawancara adalah : 79

=> Peserta Abdul Q. pada kolom wawancara $r_{1.3}=79 / 79=1$

=> Peserta Alfan D. pada kolom wawancara $r_{2.3}=74 / 79=0,936708860759490$

=> Peserta Catur A. pada kolom wawancara $\mathrm{r}_{3.3}=73 / 79=0,924050632911390$

=> Peserta Imam T. Pada kolom wawancara $r_{4.3}=73 / 79=0,924050632911390$

=> Peserta Ismiyati pada kolom wawancara $r_{5.3}=76 / 79=0,962025316455700$

=> Peserta Nur R. pada kolom wawancara $r_{6.3}=72 / 79=0,911392405063290$

=> Peserta Rizky K. Pada kolom wawancara $r_{7.3}=75 / 79=0,949367088607590$

=> Peserta Wildan H. Pada kolom wawancara $r_{8.3}=77 / 79=0,974683544303800$

Nilai maksimal pada praktek adalah : 65

=> Peserta Abdul Q. pada kolom praktek $r_{1.4}=45 / 65=0,692307692307690$

=> Peserta Alfan D. pada kolom praktek $r_{2.4}=30 / 65=0,461538461538460$

=> Peserta Catur A. pada kolom praktek $r_{3.4}=50 / 65=0,769230769230770$

=> Peserta Imam T. Pada kolom praktek $r_{4.4}=15 / 65=0,230769230769230$

=> Peserta Ismiyati pada kolom praktek $r_{5.4}=35 / 65=0,538461538461540$

=> Peserta Nur R. pada kolom praktek $r_{6.4}=65 / 65=1$

=> Peserta Rizky K. Pada kolom praktek $r_{7.4}=10 / 65=0,153846153846150$

=> Peserta Wildan H. Pada kolom praktek $r_{8.4}=50 / 65=0,769230769230770$

Nilai maksimal pada ipk/nilai sekolah adalah : 88,50

=> Peserta Abdul Q. pada kolom ipk/nilai sekolah $\mathrm{r}_{1.5}=83,40 / 88,50=0,942372881355930$

=> Peserta Alfan D. pada kolom ipk/nilai sekolah $\mathrm{r}_{2.5}=80,50 / 88,50=0,909604519774010$

=> Peserta Catur A. pada kolom ipk/nilai sekolah $r_{3.5}=74 / 88,50=0,836158192090400$

=> Peserta Imam T. Pada kolom ipk/nilai sekolah $\mathrm{r}_{4.5}=81,50 / 88,50=0,920903954802260$

=> Peserta Ismiyati pada kolom ipk/nilai sekolah $\mathrm{r}_{5.5}=88,50 / 88,50=1$

=> Peserta Nur R. pada kolom ipk/nilai sekolah

$\mathrm{r}_{6.5}=81 / 88,50=0,915254237288140$

=> Peserta Rizky K. Pada kolom ipk/nilai sekolah $\mathrm{r}_{7.5}=84 / 88,50=0,949152542372880$

=> Peserta Wildan H. Pada kolom ipk/nilai sekolah $r_{8.5}=78 / 88,50=0,881355932203390$

Nilai maksimal pada pengalaman kerja adalah : 9

=> Peserta Abdul Q. pada kolom pengalaman kerja $r_{1.6}=0 / 9=0$

=> Peserta Alfan D. pada kolom pengalaman kerja $\mathrm{r}_{2.6}=0 / 9=0$

$=>$ Peserta Catur A. pada kolom pengalaman kerja $r_{3.6}=0 / 9=0$

=> Peserta Imam T. Pada kolom pengalaman kerja $r_{4.6}=0 / 9=0$

$=>$ Peserta Ismiyati pada kolom pengalaman kerja $r_{5.6}=1 / 9=0,111111111111110$

$=>$ Peserta Nur R. pada kolom pengalaman kerja $r_{6.6}=9 / 9=1$

=> Peserta Rizky K. Pada kolom pengalaman kerja $r_{7.6}=1 / 9=0,111111111111110$

$=>$ Peserta Wildan H. Pada kolom pengalaman kerja $r_{8.6}=2 / 9=0,222222222222220$

Biasanya nilai normalisasi dituliskan atau digambarkan dalam bentuk matriks. Tetapi disini digambarkan atau diproses didalam tabel normalisasi. Dan di bawah ini diketahui hasil normalisasi untuk tiap peserta pada setiap kriteria. Semua penjelasan perhitungan di bawah ini dijelaskan sesuai pemahaman penulis dengan tujuan memudahkan pembaca dalam memahami proses perhitungan. Mungkin dilain artikel proses perhitungan dan penulisan variabel tidak seperti ini akan tetapi hasil akhir mungkin akan sama. Berikut adalah nilai normalisasi dari tiap peserta dari setiap kriteria yang sudah dihitung di atas dan dikelompokkan berdasarkan nama masing-masing.

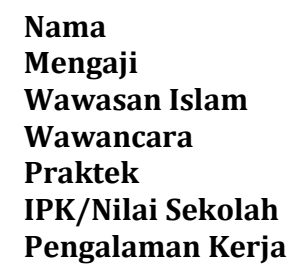

Nama

Mengaji

Wawasan Islam

Wawancara

Praktek

IPK/Nilai Sekolah

Pengalaman Kerja

Nama

Mengaji

Wawasan Islam

Wawancara

Praktek

IPK/Nilai Sekolah

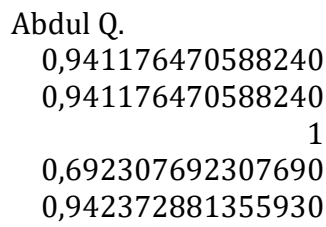

Catur A.

0,924050632911390 0,769230769230770 0,836158192090400 


\begin{tabular}{|c|c|c|}
\hline Pengalaman Kerja & : & 0 \\
\hline Nama & : & Imam $\mathrm{T}$. \\
\hline Mengaji & : & 0,705882352941180 \\
\hline Wawasan Islam & : & 0,705882352941180 \\
\hline Wawancara & : & 0,924050632911390 \\
\hline Praktek & : & 0,230769230769230 \\
\hline IPK/Nilai Sekolah & : & 0,920903954802260 \\
\hline Pengalaman Kerja & : & 0 \\
\hline Nama & : & Ismiyati \\
\hline Mengaji & : & 0,941176470588240 \\
\hline Wawasan Islam & : & 0,941176470588240 \\
\hline Wawancara & : & 0,962025316455700 \\
\hline Praktek & : & 0,538461538461540 \\
\hline IPK/Nilai Sekolah & : & 1 \\
\hline Pengalaman Kerja & : & 0,111111111111110 \\
\hline Nama & : & Nur R. \\
\hline Mengaji & : & 0,941176470588240 \\
\hline Wawasan Islam & : & 0,941176470588240 \\
\hline Wawancara & : & 0,911392405063290 \\
\hline Praktek & : & 1 \\
\hline IPK/Nilai Sekolah & : & 0,915254237288140 \\
\hline Pengalaman Kerja & $:$ & (2) \\
\hline Nama & : & Rizky K. \\
\hline Mengaji & : & 0,823529411764710 \\
\hline Wawasan Islam & : & 0,823529411764710 \\
\hline Wawancara & : & 0,949367088607590 \\
\hline Praktek & : & 0,153846153846150 \\
\hline IPK/Nilai Sekolah & : & 0,949152542372880 \\
\hline Pengalaman Kerja & : & 0,111111111111110 \\
\hline Nama & : & Wildan H. \\
\hline Mengaji & : & 0,941176470588240 \\
\hline Wawasan Islam & : & 0,941176470588240 \\
\hline Wawancara & : & 0,974683544303800 \\
\hline Praktek & : & 0,769230769230770 \\
\hline IPK/Nilai Sekolah & : & 0,881355932203390 \\
\hline Pengalaman Kerja & & 0,222222222222220 \\
\hline
\end{tabular}

Hasil ini didapatkan dari perhitungan menggunakan pemrograman PHP dan menggunakan query MySQLi dengan tipe data double $(17,15)$. Setelah mendapatkan nilai normalisasi, selanjutnya dilakukan perkalian antara hasil normalisasi dengan bobot kriteria yang ditetapkan pada setiap tes dan jumlahkan. Hitung pada masing-masing peserta.

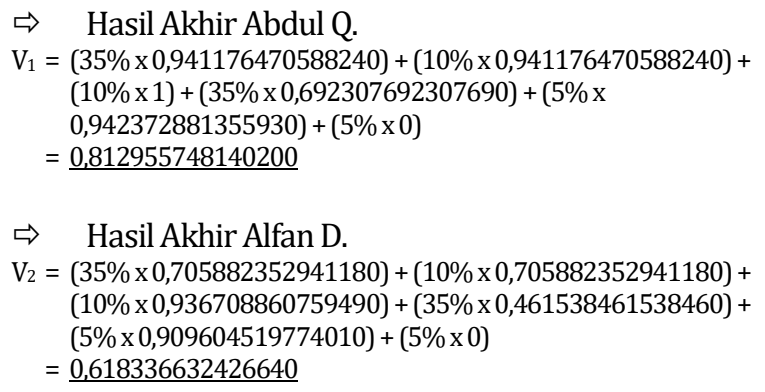

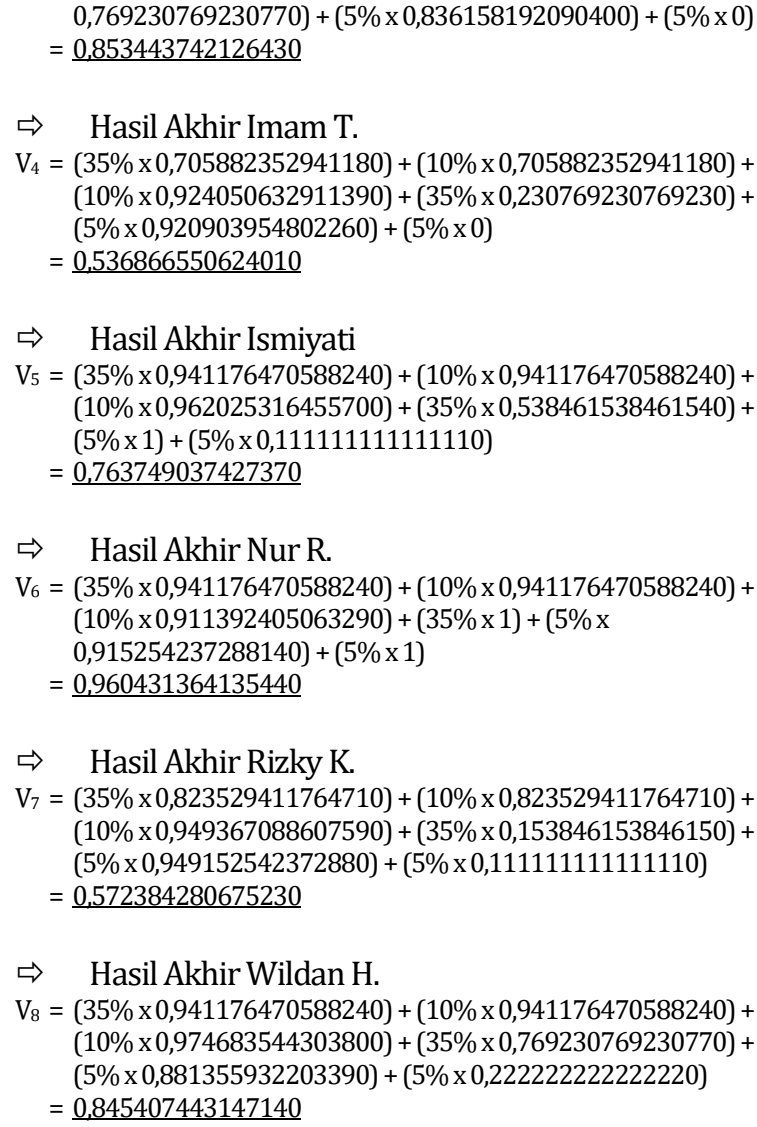

$\Rightarrow \quad$ Hasil Akhir Wildan $\mathrm{H}$.

$\mathrm{V}_{8}=(35 \% \mathrm{x} 0,941176470588240)+(10 \% \times 0,941176470588240)+$ $(10 \% \times 0,974683544303800)+(35 \% \times 0,769230769230770)+$ $(5 \%$ x 0,881355932203390$)+(5 \%$ x 0,2222222222222220$)$

$=\underline{0,845407443147140}$

Perlu diketahui hasil perhitungan ini diperoleh dari perhitungan menggunakan php dan mysqli dengan tipe data double dengan panjang nilai $(17,15)$ yang berarti panjang/nilai keseluruhan angka adalah 17 digit dan mempunyai panjang digit 15 angka di belakang koma. Kemungkinan terjadinya pembulatan angka. Setelah perhitungan nilai prefrensi $V_{i}$ didapatkan pada masing-masing peserta selanjutnya tinggal mensortir atau mengurutkan hasil perhitungan nilai prefrensi pada tiap-tiap peserta dari yang terbesar hingga ke yang terkecil.

Tabel 3. Hasil akhir/nilai prefrensi $V_{i}$ tiap peserta

\begin{tabular}{l|c}
\multicolumn{1}{c|}{ Nama } & Nilai $\mathbf{~}_{\mathbf{i}}$ \\
\hline Nur R. & 0,960431364135440 \\
\hline Catur A. & 0,853443742126430 \\
\hline Wildan H. & 0,845407443147140 \\
\hline Abdul Q. & 0,812955748140200 \\
\hline Ismiyati & 0,763749037427370 \\
\hline Alfan D. & 0,618336632426640 \\
\hline Rizky K. & 0,572384280675230 \\
\hline Imam T. & 0,536866550624010 \\
\hline
\end{tabular}

Dari Tabel hasil akhir atau nilai nilai prefrensi $V_{i}$ pada tabel 3. dan setelah dilakukan perangkingan atau diurutkan dari yang paling besar hingga yang 
paling kecil diperoleh peserta dengan nama Nur R. menjadi pelamar dengan nilai yang terbaik dari peserta lainnya.

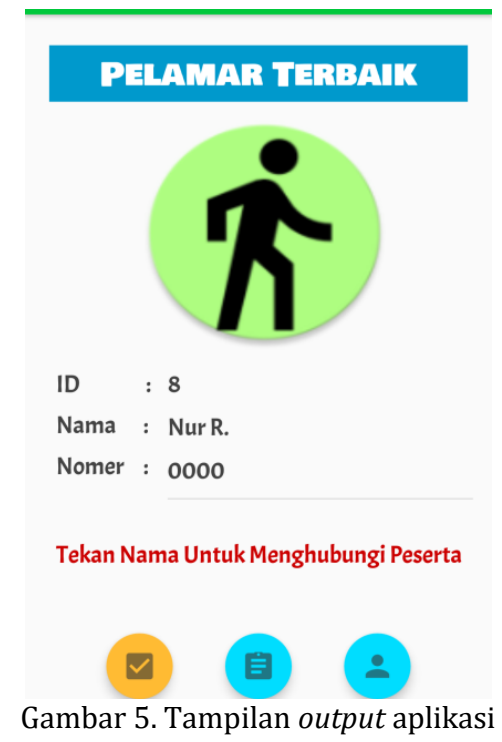

Pada gambar 5. terlihat bahwa alternatif atau peserta dengan nama Nur R. telah terpilih menjadi peserta dengan nilai terbaik. dan ditampilkan pada output atau keluaran program.

\section{PENUTUP}

Pada pembuatan program sistem keputusan penerimaan pegawai ini dapat disimpulkan bahwa program sistem pendukung keputusan ini praktis dipakai untuk alat bantu ketika seleksi tes penerimaan pegawai karena berbasis android. Aplikasi ini kurang efektif ketika data peserta atau jumlah peserta terlalu banyak. Dikarenakan menginput data dalam jumlah yang banyak akan lebih mudah penggunaannya dengan menggunakan komputer atau berbasis dekstop menurut sebagian orang. Hasil Output atau keluaran program sistem pendukung keputusan ini belum bisa memutuskan mana peserta yang direkomendasikan jika ada dua peserta yang mempunyai nilai yang sama. Sistem akan memilih secara default kepada beberapa peserta yang mempunyai nilai yang sama. Maka dari itu masih tetap diperlukan peran manusia dalam penentuannya.
Adapun saran dari pembuatan sistem pendukung keputusan ini yakni perlu adanya keberanian untuk menerapkan sistem pendukung keputusan dalam membantu tes penerimaan pegawai baru sebab akan menguntungkan banyak pihak. Baik dari peserta tes, staf bagian HRD, dan juga para penguji tes. Diharapkan ketika misalnya sistem pendukung keputusan ini diterapkan maka user akan mengambil hasil dari sistem pendukung keputusan ini secara objektif dan tidak lagi secara subjektif kecuali ada kesamaan hasil akhir dari sistem pendukung keputusan pada aplikasi ini atau mengampil langsung hasil default dari nilai yang sama persis.

\section{DAFTAR PUSTAKA}

[1] Alfalahsby, "Lembaga Pendidikan Al Falah | Berahlak Mulia dan Berprestasi," 2016. [Online]. Available: https://www.alfalahsby.com/lpfs/muqoddima h-lpf/sdm-lpf. [Accessed: 19-Jan-2019].

[2] I. Jazari, "Cara Perhitungan dan contoh Kasus Metode SAW (Simple Additive Weighting) Tutorial Teknologi Kuliah," 2016. [Online]. Available: https://informasianakutm.blogspot.com/2016/06/caraperhitungan-dan-contoh-kasus.html. [Accessed: 19-Jan-2019].

[3] E. Ismanto and N. Effendi, "Sistem Pendukung Keputusan Penerimaan Karyawan Dengan Metode Simple Additive Weighting (SAW)," SATIN - Sains dan Teknol. Inf., vol. 3, no. 1, p. 1, Jun. 2017.

[4] E. G. Wahyuni and A. T. Anggoro, "Sistem Pendukung Keputusan Penerimaan Pegawai dengan Metode TOPSIS," J. Sains, Teknol. dan Ind., vol. 14, no. 2, pp. 108-116, Jun. 2017.

[5] A. Qiyamullailiy, S. Nandasari, and Y. Amrozi, "Perbandingan Penggunaan Metode SAW dan AHP untuk Sistem Pendukung Keputusan Penerimaan Karyawan Baru," Tek. Eng. Sains J., vol. 4, no. 1, pp. 7-12, 2020. 